\title{
AUTOIMMUNE MECHANISMS OF CARDIAC REMODELING IN CHRONIC OBSTRUCTIVE PULMONARY DISEASE
}

\author{
V. Dielievska and P. Kravchun \\ Department of Internal Medicine No. 2 and Clinical Immunology and Allergology, \\ Kharkiv National Medical University, Ukraine
}

\begin{abstract}
Patients with chronic obstructive pulmonary disease (COPD) have high risk of cardiovascular events due to the remodeling of the heart and vessels. We investigated whether in COPD cardiac remodeling is associated with immune response to the inflammation by studying activated T-lymphocytes, CD3+, CD4+, CD8+ subsets of Tlymphocytes autoimmune lymphocytotoxic and granulocytotoxic antibodies, circulating immune complexes, bacterial sensibilization and hypersensitivity by the delayed type to the host heart tissue antigens. It turned out that progression of COPD is characterized by the decrease of cell immunity with formation of bacterial sensibilization and autosensibilization to the heart tissue antigens, strongly associated with cardiac remodeling. Thus, the presence of autoimmune response significantly contributes to the changes of heart geometry in patients with COPD.
\end{abstract}

Key words: leukocyte migration inhibitory factor, remodeling of the left ventricle, bacterial sensibilization, autoimmune lymphocytotoxic antibodies

Corresponding author: V. Dielievska, MD, Department of Internal Medicine No. 2 and Clinical Immunology and Allergology, e-mail: valentinka_1987@ukr.net

\section{INTRODUCTION}

hronic obstructive pulmonary disease (COPD) leads to the significant remodeling of the heart, manifesting in chronic heart failure [1].

The pathogenetic mechanisms of cardiac remodeling in COPD are complex and are the object of many studies. Since immunological disorders occupy the major place in chronic inflammatory processes due to the long-term persistence of bacterial and viral patho- gens, toxic effects of which lead to the decrease of functional activity of immune cells [2], it is of great interest to study the immune mechanisms of heart failure in COPD.

There is a limited number of studies on specific immunological parameters in COPD, such as leukocyte migration inhibition factor (LIF) and leukocyte migration activity induced by specific antigens. LIF is known to inhibit the migration of polymorphonuclear leukocytes in vitro in response to antigens or mito- 
gens. LIF is involved in host defense against bacteria as well as tissue-specific mechanisms of damage [3, 4]. LIF has emerged as a key factor of inflammatory diseases, nevertheless, its association with heart remodeling and involvement in autoimmune processes in the heart have not been reported.

The purpose of our study was to investigate the peculiarities of the immune status in patients with COPD depending on the severity of the disease and to evaluate their association with echocardiography parameters.

\section{MATERIAL AND METHODS}

We examined 42 patients diagnosed with II and III degrees of bronchoobstruction with COPD (GOLD Guidelines, 2014). Patients aged from 44 to 70 years, at average age $62.4 \pm 3.20$ years, including 25 males and 17 females. The duration of COPD ranged from 8 to 32 years, on average $-12.6 \pm 2.36$ years. The patients were divided into 2 groups. The first group consisted of 22 patients with II degree of bronchoobstruction of COPD, the second group comprised 20 patients with III degree of bronchoobstruction of COPD. The control group consisted of 20 healthy donors of corresponding sex and age.

The study of morphological and functional characteristics of the left ventricle (LV) of the heart was performed by echocardiography. Ejection fraction (EFLV), stroke volume (SVLV), end-systolic diameter (ESDLV), end-diastolic diameter (EDDLV), enddiastolic volume (EDVLV), end-systolic volume (ESVLV), posterior wall thickness (PWT), intraventricular wall thickness (IWT), left atrium diameter (LA), right atrium diameter (RA), right ventricle diameter (RV) and pulmonary artery pressure (PA) were measured.

Immunophenotyping of $T$ cells was performed by flow cytometry on the cytometer with argon-ion laser source CYTOMICS FC 500 with CXP Software (BECKMAN COULTER, USA) using anti-CD4+-FITC, anti-CD8+-PE, anti-CD3+-PC5 monoclonal antibodies (BECKMAN COULTER, USA). Each blood sample was collected by venipuncture into an EDTA tube. Erythrocytes lysis was performed with ammonium chloride. Antibody premixes were prepared and 0.1 $\mathrm{ml}$ lysed samples were added into tubes with the premixed antibodies. The samples were acquired on the cytometer for identification of CD3+, CD3+ CD4+ and CD3+ CD8+ cells by a comparison of the specific fluorescence signal according to the presence of CD3+, $\mathrm{CD} 4+$ or CD8+ antigen at the cell surface with the side scatter signal. Percentage values for CD4+ and CD8+ were derived as the number of CD4+ or CD8+ T cells divided by the total number of lymphocytes.
The percentage of T active lymphocytes ("active rosettes") was determined in T-cell-sheep red blood cells rosette formation test [5].

The levels of $\lg A$, IgM and IgG in serum were measured by ELISA kits (Human IgG total ELISA, Human IgA total ELISA, Human IgM total ELISA, eBioscience, Austria).

Determination of circulating immune complexes (CIC) in the serum was performed by precipitation method with polyethylene glycol with molecular weight of 3500 [6].

LIF production was estimated in leukocyte migration inhibition (LMI) assay by a capillary migration technique $[7,8]$. To reveal the bacteria induced leukocyte migration activity antigens of Staphylococcus aureus (St. aureus), Streptococcus pyogenes (Str. pyogenes) and Pseudomonas aeruginosa (Ps. aeruginosa) were used. The strains of bacterial cultures were killed by heating. In order to estimate LMI to the heart tissue antigens, we used tissue homogenates on $0.9 \% \mathrm{NaCl}$ solution with a final protein content of $100 \mu \mathrm{g} / \mathrm{ml}$. Leukocytes migration area was determined using an ocular micrometer. To assess LMI we calculated leukocyte migration index (MI), which corresponded to the ratio of leukocyte migration area induced by specific antigens to the leukocyte migration area in the control sample.

Levels of autoimmune lymphocytotoxic and granulocytotoxic antibodies were determined by Ivaskova et al. [9]. Lymphocytotoxic and granulocytotoxic antibodies of nonimmune origin were measured by the same method without using complement in the assay. Statistical analysis was performed by the package of the software „Statistica 10.0". Student's and Mann-Whitney $U$ tests were used to reveal the differences between the groups. A probability $(p)$ value below 0.05 was considered significant. Data are expressed as mean \pm SEM.

\section{RESULTS}

Patients with COPD demonstrated a decrease of the total number of activated T lymphocytes, CD3+, CD4+, CD8+ lymphocytes, and increase of LIF activity, levels of $\mathrm{CIC}$, IgM, lymphocytotoxic and granulocytotoxic antibodies of immune and nonimmune origin as compared to the control group. The patients with COPD also showed leukocyte migration enhancement (LME) in the presence of heart tissue antigens - Ml $1.25 \pm$ 0.02 and $1.31 \pm 0.02$. With the progression of bronchoobstruction the patients showed further decrease of CD3+ lymphocytes, activated T lymphocytes, CD8+ and increase of autoimmune lymphocytotoxic and 
nonimmune granulocytotoxic antibodies and LMI to bacterial antigens $-\mathrm{Ml}$ to St. aureus $-0.84 \pm 0.01$, MI to Str. pyogenes $-0.95 \pm 0.01$ and $\mathrm{Ml}$ to $\mathrm{Ps}$. aeruginosa $-0.83 \pm 0.01$ (Table 1).

The data of echocardiography correlated with parameters of cell and humoral immunity $(p<0.05)$ (Table 2). Thus, SVIV positively correlated with activated $T$ lymphocytes, CD3+, CD8+, LME to the heart tissue antigens and negatively - with IgM. EFIV positively correlated with activated T lymphocytes, CD3+, CIC and negatively - with IgG. ESDIV and EDDIV correlated with autoimmune lymphocytotoxic antibodies, LME to the heart tissue antigens, CIC, MI to St. aureus, Str. pyogenes and Ps. Aeruginosa. EDDlv also correlated with non-binding complement granulocytotoxic, IgG and IgM. ESVIv and EDVlv correlated with CD3+, CD4+ complement independent serum autocytotoxicity against granulocytes, CIC, LME to the heart tissue antigens, MI to the St. aureus, Str. pyogenes and Ps. Aeruginosa. EDVIv also correlated with autoimmune lymphocytotoxic antibodies, IgG and IgM. LA correlated with CD3+, CD8+, MI to St. aureus, Str. pyogenes and Ps. aeruginosa. RA correlated with IgG, IgA, IgM, MI to St. aureus, Str. pyogenes and Ps. Aeruginosa. RV correlated with IgG, $\lg \mathrm{A}, \operatorname{IgM}, \mathrm{Ml}$ to St. aureus, Str. pyogenes and Ps. aeruginosa .

PWT strongly correlated with $\lg G$, IgA, IgM, MI to St. aureus, Str. Pyogenes, Ps. aeruginosa and IWT correlated with IgA, IgM, MI to St. aureus, Str. Pyogenes, Ps. Aeruginosa. PA correlated with IgG, IgA, IgM , Ml to St. aureus, Str. pyogenes and Ps. Aeruginosa. Heart rate correlated with IgG, IgA, IgM.

$\mathrm{MI}$ to the heart tissue antigens positively correlated with $T$ active lymphocytes, IgG, IgA, IgM and negatively correlated with $\mathrm{CIC}$, complement independent serum autocytotoxicity against lymphocytes and granulocytes. MI to St. aureus, Str. pyogenes and Ps. aeruginosa correlated with $\lg \mathrm{M}, \lg \mathrm{A}$ and $\lg \mathrm{G}$. While LIF correlated with autoimmune lymphocytotoxic and granulocytotoxic antibodies $(p<0.05)($ Table 3$)$.

Table 1. Immune status of patients with COPD in bronchoobstruction progression

\begin{tabular}{|c|c|c|c|c|}
\hline \multirow{2}{*}{\multicolumn{2}{|c|}{ Parameter }} & \multirow{2}{*}{$\begin{array}{l}\text { Control group } \\
\qquad \mathrm{N}=20\end{array}$} & \multicolumn{2}{|c|}{ Patients with COPD } \\
\hline & & & $\begin{array}{l}\text { Il degree of bronchoobstruction } \\
\qquad \mathrm{N}=22\end{array}$ & $\begin{array}{l}\text { Ill degree of bronchoobstruction } \\
\qquad \mathrm{N}=20\end{array}$ \\
\hline \multicolumn{2}{|c|}{ Activated T lymphocytes, \% } & $36.7 \pm 1.3$ & $29.1 \pm 0.85^{\circ}$ & $24.2 \pm 0.74 \% 00$ \\
\hline \multicolumn{2}{|c|}{$\mathrm{CD} 3+, \%$} & $67.7 \pm 2.2$ & $55.1 \pm 1.43^{\circ}$ & $49.3 \pm 1.2 \% 00$ \\
\hline \multicolumn{2}{|l|}{ CD4+, \% } & $44.7 \pm 1.0$ & $35.7 \pm 0.84^{\circ}$ & $34.3 \pm 0.75^{\circ}$ \\
\hline \multicolumn{2}{|c|}{ CD 8+/CD16+, \% } & $23.0 \pm 0.6$ & $19.4 \pm 0.47^{\circ}$ & $15.1 \pm 0.45 \% 00$ \\
\hline \multicolumn{2}{|c|}{ Immunoregulatory index } & $1.94 \pm 0.11$ & $1.84 \pm 0.08^{\circ}$ & $2.27 \pm 0.14^{00}$ \\
\hline \multicolumn{2}{|c|}{ Lymph. antibodies, \% } & $6.0 \pm 0.37$ & $13.7 \pm 0.55^{\circ}$ & $20.0 \pm 0.78 \% 00$ \\
\hline \multicolumn{2}{|c|}{ Lymph. antibodies w/o/c, \% } & $4.0 \pm 0.1$ & $7.6 \pm 0.41^{\circ}$ & $8.21 \pm 0.44^{\circ}$ \\
\hline \multicolumn{2}{|c|}{ Gran. antibodies, \% } & $4.12 \pm 0.2$ & $8.0 \pm 0.4^{\circ}$ & $9.7 \pm 0.46^{\circ}$ \\
\hline \multicolumn{2}{|c|}{ Gran. antibodies w/o/c, \% } & $3.6 \pm 0.08$ & $7.4 \pm 0.37^{\circ}$ & $15.24 \pm 0.62 \% 00$ \\
\hline \multicolumn{2}{|l|}{$\mathrm{CIC}$, units } & $62.7 \pm 2.14$ & $77.0 \pm 3.1^{0}$ & $72.4 \pm 2.42^{\circ}$ \\
\hline \multicolumn{2}{|l|}{$\lg G, g / l$} & $11.6 \pm 0.72$ & $11.7 \pm 1.1$ & $12.94 \pm 1.11$ \\
\hline \multicolumn{2}{|l|}{$\lg A, g / l$} & $2.0 \pm 0.12$ & $2.08 \pm 0.13$ & $2.32 \pm 0.17$ \\
\hline \multicolumn{2}{|l|}{$\operatorname{lgM}, g / l$} & $1.24 \pm 0.03$ & $1.57 \pm 0.07^{\circ}$ & $1.5 \pm 0.06^{\circ}$ \\
\hline \multicolumn{2}{|c|}{ Spontaneous MI } & $1.01 \pm 0.01$ & $0.86 \pm 0.01^{\circ}$ & $0.83 \pm 0.01 \% 00$ \\
\hline \multirow{4}{*}{$\begin{array}{l}\text { Ml to the } \\
\text { antigens of }\end{array}$} & St. aureus & $1.05 \pm 0.01$ & $1.0 \pm 0.01$ & $0.84 \pm 0.01 \% 00$ \\
\hline & Str. pyogenes & $1.07 \pm 0.01$ & $1.05 \pm 0.01$ & $0.95 \pm 0.01 \% 00$ \\
\hline & Ps. aeruginosa & $1.04 \pm 0.01$ & $1.02 \pm 0.01$ & $0.83 \pm 0.01 \% 00$ \\
\hline & the heart tissue & $1.07 \pm 0.01$ & $1.25 \pm 0.02^{\circ}$ & $1.31 \pm 0.02 \% 00$ \\
\hline
\end{tabular}

Note: Lymph. antibodies - lymphocytotoxic antibodies, Lymph. antibodies w/o/c - lymphocytotoxic antibodies in reaction without complement; Gran. antibodies - granulocytotoxic antibodies, Gran. antibodies w/o/c - granulocytotoxic antibodies in reaction without complement. ${ }^{\circ}-$ values are significantly different from the control group $(p<0.05),{ }^{\circ}-$ values are significantly different from COPD patients with II degree of bronchoobstruction. 
Table 2. Correlation of echocardiography data with parameters of cell and humoral immunity in patients with COPD

\begin{tabular}{|c|c|c|c|c|c|c|c|c|c|c|c|c|c|c|c|}
\hline & \multicolumn{15}{|c|}{ Spearman's correlation coefficient, $r$} \\
\hline & 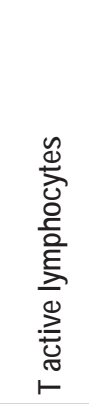 & 苛 & 寺 & 行 & 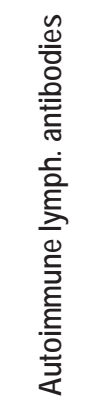 & 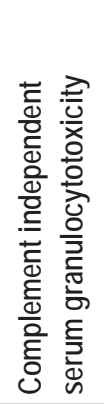 & $\frac{U}{U}$ & 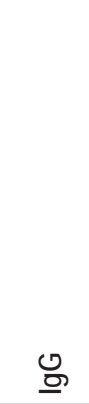 & 亞 & 흐 & 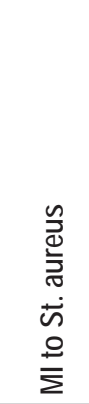 & 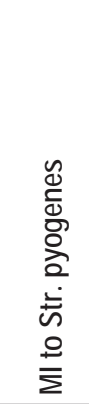 & 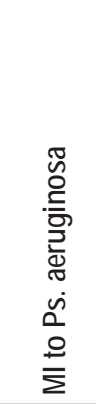 & 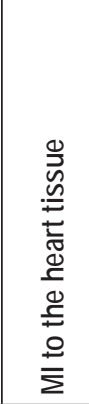 & 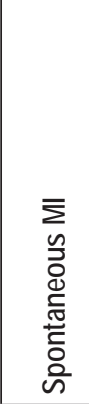 \\
\hline SV LV & $0.39 *$ & $0.52^{\star}$ & & $0.73^{\star}$ & & & & & & $-0.38^{\star}$ & & & & $0.74^{*}$ & $-0.44^{*}$ \\
\hline EF LV & $0.40^{*}$ & $0.30^{*}$ & & & & & $0.57^{*}$ & $-0.43^{\star}$ & & & & & & & $0.31^{*}$ \\
\hline ESD LV & & & & & $0.33^{*}$ & & $-0.59^{*}$ & & & & $-0.65^{*}$ & $-0.74^{\star}$ & $-0.70^{*}$ & $0.43^{*}$ & $-0.42^{\star}$ \\
\hline EDD LV & & & & & $0.30^{\star}$ & $0.30^{\star}$ & $-0.57^{\star}$ & $0.30^{\star}$ & & $-0.30^{*}$ & \begin{tabular}{|l|}
$-0.64^{\star}$ \\
\end{tabular} & $-0.70^{\star}$ & $-0.77^{\star}$ & \begin{tabular}{|l}
$0.30^{*}$ \\
\end{tabular} & \begin{tabular}{|l|l}
$-0.45^{*}$ \\
\end{tabular} \\
\hline ESV LV & & $-0.31^{*}$ & $-0.32^{\star}$ & & & $0.34^{\star}$ & $-0.59^{\star}$ & & & & \begin{tabular}{|l|}
$-0.64^{*}$ \\
\end{tabular} & $-0.73^{*}$ & $-0.71^{*}$ & \begin{tabular}{|l}
$0.54^{*}$ \\
\end{tabular} & \begin{tabular}{|l|}
$-0.34^{\star}$ \\
\end{tabular} \\
\hline EDV LV & & $-0.32^{\star}$ & $-0.30^{*}$ & & $0.34^{*}$ & $0.32^{\star}$ & $-0.57^{\star}$ & $0.32^{\star}$ & & $-0.43^{*}$ & $-0.63^{*}$ & $-0.72^{\star}$ & $-0.77^{*}$ & $0.55^{*}$ & $-0.36^{\star}$ \\
\hline LA & & $-0.50^{*}$ & & $-0.47^{\star}$ & & & & & & & $-0.64^{\star}$ & $-0.72^{\star}$ & $-0.70^{*}$ & & \\
\hline RA & & & & & & & & $-0.31^{\star}$ & $-0.30^{*}$ & $-0.30^{*}$ & $-0.65^{*}$ & $-0.77^{\star}$ & $-0.70^{*}$ & & \\
\hline RV & & & & & & & & $-0.47^{\star}$ & $-0.57^{\star}$ & $-0.57^{*}$ & $-0.77^{*}$ & $-0.77^{\star}$ & $-0.70^{\star}$ & & \\
\hline PWT & & & & & & & & $0.54^{\star}$ & \begin{tabular}{|l|l|}
$0.68^{\star}$ \\
\end{tabular} & $0.72^{\star}$ & $0.30^{*}$ & $0.86^{*}$ & $0.30^{*}$ & & \\
\hline IWT & & & & & & & & & \begin{tabular}{|l}
$0.63^{*}$ \\
\end{tabular} & $0.82^{\star}$ & $0.30 *$ & $0.86^{*}$ & $0.30^{\star}$ & & \\
\hline PA & & & & & & & & $-0.41^{\star}$ & $-0.49^{\star}$ & $-0.54^{\star}$ & $-0.89^{*}$ & $-0.77^{\star}$ & $-0.90^{*}$ & & \\
\hline Heart rate & & & & & & & & $0.67^{\star}$ & $-0.60^{\star}$ & $0.67^{*}$ & & & & & \\
\hline
\end{tabular}

Note: * only data with $p<0.05$ are presented

Table 3. Spearman's correlation analysis of parameters of immunological status in patients with COPD

\begin{tabular}{|c|c|c|c|c|c|c|c|c|c|}
\hline & 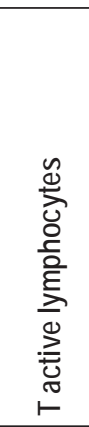 & 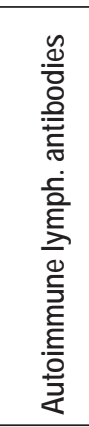 & 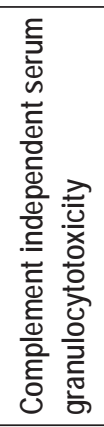 & 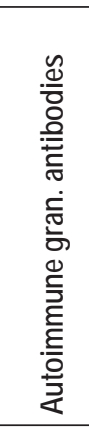 & 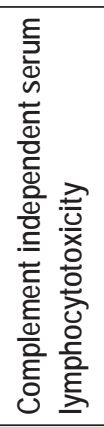 & $\frac{0}{U}$ & 으 & ธ్ర & 言 \\
\hline Spontaneous MI & & $-0.43^{*}$ & & $-0.60^{*}$ & & & & & \\
\hline Ml to St. aureus & & & & & & & $0.34^{*}$ & $0.46^{*}$ & $0.39^{\star}$ \\
\hline MI to Str. pyogenes & & & & & & & $0.60^{*}$ & $0.66^{\star}$ & $0.61^{*}$ \\
\hline MI to Ps. aeruginosa & & & & & & & $0.30^{*}$ & $0.30^{*}$ & $0.30^{\star}$ \\
\hline MI to the heart tissue & $0.53^{\star}$ & & $-0.30^{*}$ & & $-0.44^{*}$ & $-0.45^{\star}$ & $0.30^{*}$ & $0.30^{*}$ & $0.43^{*}$ \\
\hline
\end{tabular}

Note: * Only data with $p<0.05$ are presented

\section{DISCUSSION}

The obtained results clearly showed that progression of bronchoobstruction in patients with COPD leads to the decrease of parameters of cell immunity - activated T lymphocytes, CD3+, CD8+ and increase of autoimmune humoral response - autoimmune lym- phocytotoxic antibodies and complement independent serum autocytotoxicity against granulocytes. These changes are strongly associated with dilation of the left and right ventricles, left and right atria and increase of pulmonary artery pressure. Remarkably, in bronchoobstruction the patients develop severe bacterial sensibilization to St. aureus, Str. pyogenes 
and Ps. aeruginosa by the mechanism of delayed type hypersensitivity, which is strongly associated with left and right ventricles remodeling and pulmonary hypertension. It is of great importance that the patients also demonstrated autoimmune response to the heart tissue, as revealed in LMI assay in the presence of heart tissue antigens, and this autoimmune aggression contributes to the severe changes of heart geometry and function. The observed opposite correlation of EDD LV and EDV LV with IgG (positive) and IgM (negative) may testify of IgG, but not IgM contribution to the heart dilation.

Considering significant correlation of leukocyte migration to the heart tissue antigens and its structural and functional characteristics we divided the patients according to the presence or absence of LME to the heart tissue antigens to reveal the most favorable type of cell immune response for the heart remodeling (Table 4).
The comparative analysis showed that patients with LME to the heart tissue antigens develop more severe structural and functional changes of the heart as compared to the patients with normal MI. Thus, ESV LV, EDV LV, ESD LV, EDD LV, PWT, IWT, LA and EF LV were higher than those from the group with normal MI, as well as RA, RV and PA $(p<0.05)$.

Our previous studies showed that patients with COPD and $\mathrm{AH}$ develop remodeling of the LV [10, 11]. Thus, the majority of the patients with II degree of airway obstruction demonstrated concentric left ventricular hypertrophy (LVH), meanwhile progression of bronchoobstruction led to the increase of eccentric LVH incidence. To assess the immunological changes during cardiac remodeling in the present study we divided the patients into 2 groups: with concentric and eccentric LVH (Table 5).

Table 4. Structural and functional parameters of the heart in the presence of individual changes of leukocyte migration to the heart tissue antigens

\begin{tabular}{|l|c|c|}
\hline Parameter & Group 1, $\mathrm{n}=\mathbf{2 5}$ & Group 2, $\mathrm{n}=\mathbf{1 7}$ \\
\hline ESV LV, cm & $4.03 \pm 0.06$ & $3.1 \pm 0.02^{\star}$ \\
\hline EDV LV, cm & $5.51 \pm 0.08$ & $4.8 \pm 0.03^{\star}$ \\
\hline ESD LV, $\mathrm{ml}$ & $72.03 \pm 4.65$ & $39.0 \pm 0.6^{\star}$ \\
\hline EDD LV, ml & $154.13 \pm 9.42$ & $108.0 \pm 4.74^{\star}$ \\
\hline LA, sm & $4.33 \pm 0.03$ & $4.2 \pm 0.01^{\star}$ \\
\hline EF LV, \% & $53.63 \pm 0.54$ & $63.1 \pm 1.0^{\star}$ \\
\hline RA, cm & $3.85 \pm 0.03$ & $3.78 \pm 0.01^{\star}$ \\
\hline RV, cm & $2.78 \pm 0.03$ & $2.7 \pm 0.01^{\star}$ \\
\hline PA, mm Hg & $23.0 \pm 0.7$ & $17.0 \pm 0.64^{\star}$ \\
\hline PWT, cm & $1.39 \pm 0.01$ & $1.3 \pm 0.01^{\star}$ \\
\hline IWT, cm & $1.29 \pm 0.01$ & $1.2 \pm 0.01^{\star}$ \\
\hline
\end{tabular}

Note: ${ }^{*}-p<0.05$.

Group 1 - the patients with MI to the heart tissue antigens $1.53 \pm 0.01$

Group 2 - the patients with MI to the heart tissue antigens $1.10 \pm 0.01$

Table 5. Immunological changes in patients with COPD associated with concentric and eccentric types of left ventricular hypertrophy

\begin{tabular}{|l|c|c|}
\hline Parameter & $\begin{array}{c}\text { Concentric LVH } \\
\mathbf{n}=\mathbf{2 4}\end{array}$ & $\begin{array}{c}\text { Eccentric LVH } \\
\mathbf{n}=\mathbf{1 8}\end{array}$ \\
\hline Spontaneous MI, mean \pm SEM & $0.87 \pm 0.01$ & $0.59 \pm 0.01^{*}$ \\
\hline MI to the heart tissue antigens, mean \pm SEM & $1.32 \pm 0.02$ & $1.5 \pm 0.03^{*}$ \\
\hline CIC, units & $84.5 \pm 3.4$ & $60.5 \pm 2.0^{*}$ \\
\hline Autoimmune lymph. antibodies, \% & $12.2 \pm 0.51$ & $18.5 \pm 0.64^{\star}$ \\
\hline Autoimmune gran. antibodies, \% & $9.0 \pm 0.45$ & $10.75 \pm 0.47^{\star}$ \\
\hline MI to St. aureus, mean \pm SEM & $0.86 \pm 0.01$ & $1.23 \pm 0.02^{\star}$ \\
\hline MI to Str. pyogenes, mean \pm SEM & $1.0 \pm 0.01$ & $0.94 \pm 0.01^{\star}$ \\
\hline MI to Ps. aeruginosa, mean \pm SEM & $0.79 \pm 0.01$ & $1.2 \pm 0.02^{*}$ \\
\hline
\end{tabular}

Note: * $-p<0.05$ 
It was revealed that dilation of the LV was associated with high levels of LIF, CIC, autoimmune lymphocytotoxic and granulocytotoxic antibodies and LME to the heart tissue and bacterial antigens of St. aureus and Ps. aeruginosa.

The decrease of $\mathrm{CIC}$ in eccentric LVH as compared to the patients with concentric LVH might be explained by their deposition in the target organs, especially in the heart, causing their damaging effect and leading to the changes of its architecture. This is consistent with their negative correlations with ESD LV, EDD LV, ESV LV, EDV LV, EF LV, LA and LME to the heart tissue antigens.

Since remodeling of the LV was associated with high LIF and LME to the heart tissue antigens, we assume that high LIF production in the presence of bacterial antigens despite its defensive role towards pathogenic bacteria, also causes heart damage by the mechanism of autoimmune attack with autoimmune lymohocytotoxic and granulocytotoxic antibodies involvement as revealed in correlation analysis. It should be mentioned that both inhibition and stimulation of leukocyte migration to bacterial or tissue antigens depend on either leukocyte migration inhibiting or stimulating factors produced by macrophages, which present antigen to lymphocytes and are responsible for the initial level of LIF or macrophage stimulating factor (MStF) [12].

Thus, leukocyte migration assay helps not only to identify the presence of autoimmune processes in the heart with COPD, but also to control the effectiveness of conducted therapy, prevent further cardiac remodeling and decrease cardiovascular risk. Whereas medicine aimed to reduce the level of autoimmune lymphocytotoxic and granulocytotoxic antibodies, it might be of benefit in the treatment of chronic heart failure in COPD and requires further investigations.

\section{REFERENCES}

1. Global Initiative for Chronic Obstructive Lung Disease (GOLD): Global Strategy for the Diagnosis, Management, and Prevention of COPD. 2013.

2. Inoue, S., Nakamura, H., Otake, K. et al. 2003. Impaired pulmonary inflammatory responses are a prominent feature of streptococcal pneumonia in mice with experimental emphysema. Am J Respir Crit Care Med 167:1287.

3. Imai, C., Uno, K., Kakihara, T., et al. Vincristine-induced Fever in a Child With Rhabdomyosarcoma: Cellular Hypersensitivity to Vincristine Demonstrated by Leukocyte Migration Test. Journal of Pediatric Hematology/Oncology 2001,23(1):76.

4. Manabu, A., Yagi, M., Wakasugi, et al. A Study of Elevated Interleukin-8 (CXCL8) and Detection of Leukocyte Migration Inhibitory Activity in Patients Allergic to Beta-Lactam Antibiotics. Allergology International 2011,60(4):558.

5. Catsimoopal N. Methods of Cell Separation, Springer Science \& Business Media (ed.), 2013, 161-162.

6. Haskova, Y., Kaslic J., Riha, I. et al. Simple method of circulating immune complex detection in human serum by polyethylenglycol precipitation. Z Immunitaforsch 1978,154(4):408.

7. Krymkina, T.N., Sokolova, E.V., Petrov, R.V., Koval'chuk, L.V. Test spontannoj migracii lejkocitov perifericheskoj krovi. Metod. Rekom. Min. zdrav. RSFSR "Ocenka spontannoj migracii lejkocitov i produkcii faktora, ingibirujushhego migraciju lejkocitov krovi, u cheloveka" 1983, 4-6.

8. George, M., Vaughan, Jh. 1962. In vitro cell migration as a model for delayed hypersensitivity. Proc Soc Exp Biol Med 111(2):531.

9. Isaeva, A. D., Novachenko, T. M., Delevskij, Ju. P. et. al. Profilaktika i lechenie nevynashivanija beremennosti i lejkocitarnoj nesovmestimosti: metod. rekom. 1975,19.

10. Kravchun P. Delevskaya V. Puculiarities of left ventricular remodeling in arterial hypertension associated with chronic obstructive pulmonary disease. Bulletin of biology and medicine problems. 2014. 3, 2(111). 148-151.

11. Delevskaya V.Y. The influence of spironolactone on extracellular matrix metabolism in patients with arterial hypertension and concomitant chronic obstructive pulmonary disease. I Bulletin of Vitebsk state medical university. 2015, 14(3);38-43.

12. Méndez-Samperio, P., Jiménez-Zamudio, L., Favila-Castillo, L. Production of leukocyte migration inhibition factor (LIF) and migration stimulation factor (MStF) by $\mathrm{CD} 4+$ and $\mathrm{CD} 8+$ human lymphocytes subsets and T-cell clones. Revista de investigacion clinica 1989,41(2):107-115. 